\title{
Discussion "City of Bitlis 2014 Air Pollution Emission Inventory" Comments (2015; 5(2): 75-80)
}

\author{
Edip AVŞAR ${ }^{\text {a,* }}$ \\ a Bitlis Eren University, Department of Environmental Engineering, TR-13000, Bitlis Turkey
}

\begin{abstract}
ART I C L E I N F O
Discussion history:

Received 25 October 2018

Received in revised form 30 November

2018

Accepted 30 November 2018

Keywords:

Air pollution

Emission inventory

Bitlis

(C) 2019. Turkish Journal Park Academic. All rights reserved.
\end{abstract}

\section{Discussion}

Turp and Turp (2015) calculated emission inventory for $\mathrm{SO}_{\mathrm{x}}$, $\mathrm{NO}_{\mathrm{x}}, \mathrm{PM}_{10}$ and $\mathrm{CO}$ parameters by using the coal data burned in Bitlis for domestic heating by the year 2014 .

I have several concerns about the fuel amounts consumed and emission inventory estimation section of the study and all of them detailed below.

In the Turp and Turp (2015), the amount of coal burned in Bitlis Province was given as $32802 \mathrm{~kg}$ in 2014 and the whole emission inventory was calculated according to this value.

However, according to the Bitlis Province Environmental Status Report (ESR) by the year 2014 referred in the publication, it is stated that;

- 32960 tons of imported coal

- 11273 tons of social assistance foundation coal provided by Turkish Coal Foundation and

- $\quad 800 \mathrm{~m}^{3}$ of fuel oil

were burned in Bitlis for the aim of domestic heating in 2014 (ÇŞM, 2015).

Fuel types and specifications were given in Table 1 and Table 2 below (ÇŞM, 2015).
Table 1. Coal consumption values and specifications for Bitlis by year 2014 (ÇŞM, (2015) Table A.4, page: 25).

\begin{tabular}{|c|c|c|c|c|}
\hline \multirow[t]{2}{*}{ Fuel Type } & \multirow[t]{2}{*}{ Origin } & \multirow{2}{*}{$\begin{array}{l}\text { Consumption } \\
\text { value } \\
\text { (ton) }\end{array}$} & \multicolumn{2}{|c|}{ Fuel specification } \\
\hline & & & $\begin{array}{l}\text { Lower } \\
\text { heating } \\
\text { value } \\
(\mathrm{LHW}) \\
(\mathrm{kcal} / \mathrm{kg})\end{array}$ & $\begin{array}{l}\text { Total } \\
\text { Sulphur } \\
(\mathrm{S} \%)\end{array}$ \\
\hline $\begin{array}{l}\text { Imported } \\
\text { coal }\end{array}$ & $\begin{array}{l}\text { Coal sales } \\
\text { offices }\end{array}$ & 32960 & 6800 & $0.4-0.5$ \\
\hline $\begin{array}{l}\text { Social } \\
\text { assistance } \\
\text { foundation } \\
\text { coal }\end{array}$ & $\begin{array}{l}\text { Social } \\
\text { assistance } \\
\text { foundation }\end{array}$ & 11273 & 4200 & 1 \\
\hline
\end{tabular}

Table 2. Fuel oil consumption value for Bitlis by year 2014 (ÇŞM, (2015), Table A.7, page:26).

\begin{tabular}{|l|l|}
\hline Fuel Consumption Type & Consumption value (m3) \\
\hline Domestic & 800 \\
\hline Industrial & - \\
\hline
\end{tabular}

According to Table 1 and Table 2, totally 44230 tons of coal and $800 \mathrm{~m}^{3}$ of fuel oil were burned in Bitlis in 2014. In this case, the amount of coal used in the emission inventory calculation in Turp and Turp (2015) was 1348 times smaller than the amount burned in Bitlis. In addition, the amount of fuel oil burned was not taken into the account in the calculation of the emission inventory in Turp and Turp (2015). According to several 
studies in the literature it can be seen that whole fuel types and consuptions are taken into account in terms of emission inventory estimation (Kaynakoğlu, 2010; Odabaş 2009).

Accordingly, the values in all figures given by Turp and Turp (2015) (Between Figure 2.1 and Figure 2.16) are incorrect.

Turp and Turp (2015) used Air Pollutant Emission Inventory Guidebook (APIG) to obtain emission factors and by means of these emission factors emission inventory was estimated. However, there is no reference to this resource document in the text (EEA, 2016).

Turp and Turp (2015) stated that the sulfur content (S\%) and LHW were taken as $1.2 \%$ and $5731 \mathrm{kcal} / \mathrm{kg}$ respectively in the calculation of $\mathrm{SO}_{2}$ emission factors given in EEA (2016). According to Turp and Turp (2015), this situation was not compatible with the type and characteristics of coal used in Bitlis. Therefore, the values given in the Regulation on Air Pollution Caused by Domestic Heating (RAPCDH) were used for the calculation of the $\mathrm{SO}_{2}$ emission factors for imported (S\%: 1; LHW: $6400 \mathrm{kcal} / \mathrm{kg}$ ) and local coal (S\%: 2; LHW: 4800 $\mathrm{kcal} / \mathrm{kg}$ ) and tabulated in Table 2.2 in Turp and Turp (2015).

On the other hand, LHW and S\% content of coal used in Bitlis were given in the 2014 Bitlis ESR (Table 1 and Table 2). According to these values it can be seen that the coal specifications used in the $\mathrm{SO}_{2}$ emission factor calculation in Turp and Turp (2015) did not correspond to the coal specification used in Bitlis.

As an approach, the weighted average S\% and LHW values can be calculated by taking the LHWs, S\% contents and consumption values of two different coal types used in Bitlis. The calculations are given in Equation 1 and Equation 2

$\% S=\frac{((32960 \text { tons } x 0.5)+(11273 \text { tons } x 1))}{(32960+11273) \text { tons }}=\% 0,627$

$L H W=\frac{((32960 \times 6800)+(11273 \times 4200)) \text { tons } x \frac{\mathrm{kcal}}{\mathrm{kg}}}{(32960+11273) \text { tons }}=6137 \frac{\mathrm{kcal}}{\mathrm{kg}}$

It can be seen from the Equation 1 and 2 that the coal specifications taken by the Turp and Turp (2015) in terms of $\mathrm{SO}_{2}$ emission factors calculation did not match with the actual situation.

According to Table 2.2 in Turp and Turp (2015), SO2 emission factors were calculated for both imported and local coal. Also two different emission factors were given for other pollutants. However, emission inventory was calculated only for local coal. In this case, emission factors for imported coal were unnecessary and did not used by authors.

In addition, when the emission factors given by Turp and Turp (2015) for the burning of imported coal in the stove in Table 2 were examined, it can be seen that three emission factors listed below were incorrect.
- $\quad 1717.98 \mathrm{~kg} \mathrm{SO}_{2} /$ ton coal;

- $\quad 1212.04 \mathrm{~kg} \mathrm{PM} 10 /$ ton coal and

- $\quad 13133.76 \mathrm{~kg} \mathrm{CO} /$ ton

According to these emission factors when 1 ton of coal burned approximately;

- $\quad 1.7$ tons of $\mathrm{SO}_{2}$

- $\quad 1.2$ tons of $\mathrm{PM}_{10}$ and

- $\quad 13.1$ tons of CO

would be emitted to the atmosphere. This case is impossible. Furthermore, there were several emission factors in Table 2.2 but there were no reference about to which table they were taken in APIG. Since APIG does not have a single table and single burner type, table number in the APIG which emission factor taken should be given as an additional column in Table 2.2 .

When Table 2.1 given in Turp and Turp (2015) is examined, it can be seen that the values and the total value are numerically incorrect. In addition, the amount of coal burned in July and August was close to the amount of coal burned in December. Therefore, this data is considered to be the amount of coal sold in Bitlis, not the coal burned. Also in the emission inventory studies, it is generally accepted that fuel is not burned in the period between May and September. However, in this study it was accepted that it was burned between May and September (Kaynakoğlu, 2010; Odabaş 2009). As a result, emission inventory calculated in the study were fully incorrect due to the incorrect burned fuel data.

\section{References}

ÇŞM, (2015). Bitlis İl Çevre ve Şehircilik Müdürlüğü, Bitlis İli 2014 Yılı Çevre Durum Raporu, http://webdosya.csb.gov.tr/db/bitlis/icerikler/2014-cevre-durumraporu-20180226094425.pdf [Accessing date: 10.18.2018]

EEA, (2016). Europen Environment Agency, Air Pollutant Emission Inventory Guidebook,

https://www.eea.europa.eu/publications/emep-eea-guidebook-2016 [Accessing date: 10.18.2018]

Kaynakoğlu H., (2010). Isınma Kaynaklı Emisyon Envanterinin Hazırlanması. Büyükșehirlerde Hava Kalitesinin Geliștirilmesi Projesi,

http://ikonair.cob.gov.tr/ikonair/Files/sunumlar_cal\%C4\%B1stay/3. $\% 20$ calistay/\%C4\%B1s\%C4\%B1nma\%20envanteri.pdf [Accessing date: 10.18 .2018$]$

Odabaş B.B., (2009). Adapazarı İlçesinde Isınma Kaynaklı Emisyonların Analizi ve Envanterlenmesi. Sakarya Üniversitesi Fen Bilimleri Enstitüsü,

http://www.sahakk.sakarya.edu.tr/documents/presentations/Heatin g_sourced_emissions_inventory_TEZ.pdf [Accessing date: 10.18.2018]

Turp S.M., and Turp G.A., 2015. City of Bitlis 2014 Air Pollution Emission Inventory. Bitlis Eren Univ J Sci \& Technol., 5 (2), 75 - 80. 